\title{
TURNING THE CORNER
}

\author{
JOHN BURGE, President, A.A.S.E.
}

Councillors left the February meeting of the Australian Association of Special Education, in Sydney, in a confident and constructive frame of mind. It seems as though the Association may have turned the corner.

Some important and far reaching decisions were made, which have the potential to steadily mould the Association into a cohesive and comprehensive group, with great potential to pursue its aims at local, state and national level. A tribute should be paid to all councillors for their diligent pursuit of these themes. It is often easier to ignore the need for change but councillors have persisted in their dicussion with growing enthusiasm. It is important that their vision be given a good hearing in constructive debate in state associations.

The sub-committees instituted at Canberra last July have been working effectively. Particularly speedy and efficient work was achieved by the Teacher Education Sub-committee. A statement has been constituted, and sumbitted to the Minister for Education, Mr. Fife, concerning the Association's views on teacher education in the special education area. This is a further step forward for the Association in the development and advocacy of policy.

The Multidisciplinary Sub-committee has been carefully developing contacts amongst State associations, persons in tertiary institutions and sites for the operation of multidisciplinary approaches. During the next six months, the Subcommittee will promulgate various positions, and endeavour to gain reactions from the group of contact personnel which it has established. The outcome of this activity will lead to the establishment of a policy document on multidisciplinary approaches to the provision of special education for the Association.

The Funding Sub-committee has been frustrated in its efforts to develop ways and means of better funding and facilitating the work of the Association. A major setback occurred in November, 1980, when the Minister for Transport, Mr. Hunt, announced that airlines would no longer be able to offer any assistance to associations such as ours. Prior to this, we had been in receipt of some assistance from one of the airlines, and this was useful in defraying the accumulated costs of travel to Council Meetings. I should mention here, again, that all councillors who travelled to the meeting in Sydney in February, did so at their own expense; costs were then shared amongst all attenders.

A great deal of time at the February meeting was devoted to discussion of the report of the Consititution Subcommittee. The Sub-committee report outlined the major components for the structure of a new consititution for the Association, a structure which would take the Association into a national body, operating at three levels: national, state and local. The substantive components of the Constitution Sub-committee's submission were accepted by the Council of the Association, and the Sub-committee instructed to proceed with the drawing up of a complete constitution for presentation at the Annual General Meeting of the Association in August. This constitution will be distributed to affiliated associations before that meeting, so that there will be ample time for discussion amongst state executives and members.

It is particularly pleasing to report that the financial situation of the Association is vastly improved in this 1981 year. Although finances must be carefully watched, funds are now available to predict confidently, the preparation and printing of the Journal. It is anticipated that by the middle of this 1981 year, Journal production will be up to date, and there will be held in advance copy and funds for the next Journal. This has been a long sought goal of the Journal Editor and the Executive. It is now within reach.

So that individual members might become aware of policy, I have in the past printed policy statements, and aims of the Association, in these columns. To continue this practice, I am presenting on this occasion, the report of the Teacher Education Sub-committee which was adopted by the Council in February. A draft was also submitted to the Minister for Education a short time earlier. It should be noted here that the thanks of the Executive, the Council and members of the Association are very much due to Paul Duerdoth, the convenor of the Teacher Education Subcommittee, for a great deal of effort spent in the preparation and collation of the document. 